\title{
Lay theories of quality of life in older age
}

\author{
ANN BOWLING* and ZAHAVA GABRIEL*
}

\begin{abstract}
This paper presents findings from a national survey of quality of life (QoL) in older age. The main aim of the analyses was to examine the definitions of quality of life given by people aged 65 or more years and the underlying reasons. Openended questions were used to elicit their perceptions of QoL. These were followed by structured measures of self-rated QoL overall, and of domains of QoL commonly reported in the literature. The main things said by the respondents to give their lives quality were categorised into 'themes'. These were: social relationships; social roles and activities; leisure activities enjoyed alone; health; psychological outlook and wellbeing; home and neighbourhood; financial circumstances; and independence. The reasons people gave to explain why these things were important to their QoL focused on: the freedom to do the things they wanted to do without restriction (whether in the home or socially); pleasure, enjoyment and satisfaction with life; mental harmony; social attachment and having access to companionship, intimacy, love, social contact and involvement, help; social roles; and feeling secure. This paper also presents data that demonstrates the ability of theoretically informed, structured survey indicators of QoL to predict respondents' self-rated overall QoL. Logistic regression analyses showed that most of these indicators were strong, independent predictors of self-ratings of QoL, although those that were not significant in the model did not fully incorporate lay reasons of QoL in their measurement scales. In conclusion, the indicators which were not significant in the model did not fully incorporate lay values in their measurement properties. It is also likely that those indicators that were significant could have been improved.
\end{abstract}

$\boldsymbol{K E Y} W O R D S-$ quality of life, ageing, social support, social roles, health, wellbeing.

\section{Background}

Quality of life (QoL) has become a commonly used end-point in the evaluation of public policy in many human services sectors. This indicates that a multi-faceted perspective on QoL is required, with a shift away from approaches which focus only on single domains or areas of life (e.g. health).

* Department of Primary Care and Population Sciences, University College London. 
The subjectivity of the concept suggests that it should reflect the views of the population concerned. QoL is a concept which is dependent on the perceptions of individuals, and is likely to be mediated by cognitive factors (Bowling 2005a, 2005b). It is also a collection of multiple objective and subjective dimensions which interact (Lawton I982, I983 $a$, I983 $b$, I99I). There are few empirical data on the extent to which the items included in most measurement scales of QoL have any relevance or meaning to people and their everyday lives (see Bowling 200I, 2005a, 2005b; Rogerson et al. 1989), or on what proportion of people have problems in one domain of QoL and simultaneously in others. Inter-relationships and overlaps are complex to measure (Grundy and Bowling I999; Skevington, O'Connell, and the WHOQOL Group 2004). There has long been a need to integrate knowledge in this area.

QoL theoretically encompasses a person's individual characteristics (e.g. physical and mental health, psycho-social wellbeing and functioning, including feelings of independence and control over life) and external circumstances (e.g. socio-economic conditions, work, built environment and social capital). But there is debate about whether these domains are predictors of QoL or constituents of the concept itself (Bowling 200I, $2005 a$; Sarvimäki and Stonbuck-Hult 2000). The concept is often not defined in the literature, and investigators seldom justify their selection of QoL measures (Carver et al. 1999). This has resulted in many investigators adopting an implicit, narrow or discipline-bound perspective on QoL, and to accept single domain measures as sufficient (e.g. health status and physical functioning) (see Bowling 2005 $a$; Haywood et al. 2004 for reviews of measures).

Moreover, disparate models of quality of life that have been developed. Some investigators have used a needs-based satisfaction model (Higgs et al. 2003; Hyde et al. 2003) based on Maslow's (1954, 1968) hierarchy of human needs and self-actualisation. Others' conceptualisations have been based primarily on the overlapping concepts of 'the good life', 'life satisfaction', 'social wellbeing', 'morale', 'the social temperature', or 'happiness' (Andrews 1986; Andrews and Withey 1976; Lawton 1996). The focus among psychologists has been increasingly on the possession of psychological resources (selection, optimisation, compensation) for meeting the challenges of old age (Baltes and Baltes 1990). The World Health Organisation's WHOQOL Group adopted a multifaceted approach, while emphasising subjective perceptions, values and cultural context, from which has been developed their (WHOQOL) QoL measures (World Health Organisation 1993; Skevington 1999; Skevington, Lotfy and O'Connell 2004). Development work showed that common factors which contributed to QoL included family relationships, independence, a 'can

\section{CAMbridge}


do' and a positive approach to life, good health, and religious trust (Stenner, Cooper and Skevington 2003; http://www.euro.who.int/ ageing/quality). However, the reasons why these domains are important to people's QoL are relatively unexplored. Information on these is important for understanding potential causal pathways.

There have been few phenomenological approaches to exploring meaning in quality of life (i.e. the reasons why, and in what way, specific areas of life contribute to its quality); few models are truly grounded in lay views. Popay (2006), in the context of population health, argued that lay theories "challenge the authority of professionals to determine the way in which problems are defined', are "a challenge to the "objectivity" of expert "theories", and questioned whether the process of 'objectification' permits true understanding (2006:572). She argued that they were a means for people to re-assert their control through an emphasis on indirect rather than direct mechanisms, which enhances our understanding of causal processes. She contrasted quantitative modelling approaches with 'the theories we all develop as lay people as we seek to make sense of our experience [and that] are interpretations and elaborations of the meaning of causal factors in the context of everyday life. In Max Weber's terms, they provide understanding in terms of both cause and reasons' (2006: 57I). This theory holds that the only way of understanding social systems is to examine the reasons that people give for their actions.

This paper presents the main attributes (themes) that older people said gave their lives quality, and, more exceptionally, their underlying reasons. The findings provide insight into what constitutes QoL in old age.

\section{Aim and methods}

The main aim of the analyses presented here was to raise understanding of the reasons older people give about why specific areas of life contribute to its quality. These analyses are based on lay theory (Popay 2006), although the study used mixed methods rather than adopting a truly phenomenological, qualitative approach. It built on the open-ended approach of the Schedule for the Evaluation of Individual Quality of Life (SEIQoL) (O'Boyle 1997). This individualised measure takes a phenomenological perspective and uses the value system of the individual being assessed rather than that of others. It departs from phenomenology in its development of a structured, individualised measure following the deductive method, and in aggregating individual responses (Bowling 2002). A further aim of the analyses presented here was to assess quantitatively the independent ability of the theoretically informed, structured survey

\section{CAMbridge}


indicators of QoL (i.e. those which were derived from the literature, and which were administered after open-ended survey questions on QoL) to predict respondents' self-rated overall QoL. For this, logistic regression analyses were used.

The data were derived from a national interview survey of quality of life in old age in Britain. The survey sample was derived from four quarterly Office for National Statistics (ONS) Omnibus Surveys in Britain during 2000/I. Omnibus surveys aim to generate representative population samples by use of a small-user postcode sampling frame, with geographical and socio-economic stratification. All respondents aged 65 and over who were interviewed were asked if they would be willing to be re-interviewed by ONS interviewers for our module on Quality of Life. Those who consented were re-interviewed two months later. The overall response rate to the Omnibus Surveys was 62 per cent $(6,7 \mathrm{II})$. Of the sample of $\mathrm{I}, 299$ eligible respondents aged 65 or more years sifted by ONS from the Omnibus Surveys, the overall response rate was 77 per cent (999), with I9 per cent refusing to participate, and four per cent not contactable during the interview period. The socio-demographic characteristics of the sample were similar to those from mid-year population estimates for Great Britain (estimated from the last census). Full details of the method and sample have been published elsewhere (Bowling 2005 b; Bowling et al. 2002; 2003; Bowling and Gabriel 2004; Gabriel and Bowling 2004). The main themes of QoL mentioned by respondents have been published elsewhere (Bowling 2005 b; Bowling et al. 2003; Gabriel and Bowling 2004). The data presented in this paper on the relationships between these QoL themes and the reasons underlying them ('meaning sub-themes'), have not previously been published.

\section{Open-ended survey questions on $Q_{0} L$ and analysis}

Open-ended questions were asked at the beginning of the interview in order to elicit respondents' own descriptions of quality of life, both good and bad, their prioritisation of these things, how quality of life can be improved for themselves and for others of their age. The interviewers probed about the ways in which the areas of life mentioned enhanced the respondents' life quality. For example, if the respondents gave good health as a constituent of QoL, they were asked in what way, and what it was about health that gave quality to their lives. This was followed by a selfrating of the quality of their lives overall on a seven-point Likert scale, ranging from 'As good as can be' to 'As bad as can be'. These questions were asked before administering batteries of structured questions in order to prevent respondent bias.

\section{CAMBridge}


In the subsequent categorisation of responses from these open-ended survey questions, the authors followed the principles of thematic categorisation in qualitative methodology. The open-ended interview responses were transcribed. Each script was read by two independent coders, and a thematic coding frame developed. Thematic categorisation was undertaken and checked independently to ensure methodological rigour. All disagreements were discussed and categorisation agreed. Both main themes and detailed sub-themes (reasons) were coded in order to capture the essence of people's definitions and exactly what made the quality of life good and bad, and how life could be improved. The categorised QoL themes and reasons were explored using descriptive analyses (frequency distributions, means and chi-squared tests).

The main themes and sub-themes (reasons) identified were subsequently validated in qualitative, in-depth interviews with a sub-sample of 80 of the QoL survey respondents. They were purposively selected using a grid displaying their socio-demographic, socio-economic and survey responses, to ensure that a wide range of respondents were included. They included 40 men and 40 women, aged between 65 and 80 years; one-half were married and just under one-half had an income of less than $£ 6,240$ per annum (Gabriel and Bowling 2004). These in-depth interviews, and their analysis, used grounded hermeneutic methods, which enabled themes to emerge from the respondents' own stories, and the use of methods of constant comparison (see Donovan and Saunders 2005). ${ }^{1}$ Each script was read by two independent coders and a thematic coding frame developed. Thematic categorisation was undertaken and checked independently to ensure methodological rigour. In order to facilitate comparisons between the themes identified from open-ended survey responses and the in-depth interviews, a single set of category headings of the main themes was used. While it was found that the category labels of most of the sub-themes were shared between the survey and the in-depth interviews, more varied sub-themes emerged from the in-depth interviews, so they were categorised separately.

\section{Structured survey measures}

As stated earlier, the structured questions were administered after the open-ended questions on QoL to avoid influencing people's perspectives on QoL. These all tapped domains of QoL commonly reported in the literature, and which were judged important to measure from an 'expert's' perspective. They included: Sherbourne and Stewart's (I99I) and Cooper et al.'s (I999) scales of social support and perceived neighbourhood environment; Schwarzer's (1993) self-efficacy scale; Scheier and Carver's

\section{CAMBRIDGE}


(I985) optimism-pessimism scale; Lau, Hartman and Ware's (1986) health values scale; the 12 item General Health Questionnaire (GHQ-I2) for psychological morbidity (Goldberg and Williams I988); Townsend's (1979) physical functioning (activities of daily living-ADL) scale; self-rated health status (Ware et al. I993, I997); social activities, loneliness, life expectations, perceived risks, and diagnosed medical conditions. Standard socio-demographic and socio-economic items and classifications were also incorporated, including the UK National Statistics socio-economic classification (NS-SEC) (Office for National Statistics 2000).

\section{Multivariable analysis}

Logistic regression analysis was used to examine independent associations between the structured survey measures and respondents' self-rated QoL, after checks for multicollinearity. The variables selected for inclusion in the multivariate modelling overlapped with older people's definitions of QoL (themes and reasons underlying them). However, not all of their values were represented. A further survey, which measured each of these, would be required to test their independent contributions to self-rated QoL. A hierarchical approach was used, with the entry of independent variables in theoretical order of importance. The level for statistical significance was set at 0.05. To avoid the tautological effects of using domains of QoL as both predictors and constituents of QoL, the global self-rated QoL uniscale was used as the dependent variable in the quantitative analyses (Fayers and Hand 2002).

\section{Results}

Age and gender of the respondents

Of the QoL survey respondents, 62 per cent (624) were aged $65-74$ years and $3^{8}$ per cent (375) were aged 75 or more years. Just under one-half $(48 \%, 480)$ of all 999 survey respondents were female. Almost all $(98 \%$, 983) were white, as expected from a nationally-representative survey of older people in Britain. The 200 census statistics showed that 93 per cent of people of all ages in Britain were white, with a lower proportion in older age groups (see www.statistics.gov.uk/census200i/profiles/commentaries/ ethnicity.asp).

\section{Quality of life}

Similar proportions of men and women in each age group rated their overall quality of life as good or less than good. Just four per cent (2I) of

\section{CAMBRIDGE}


males and six per cent (32) of females rated their quality of life as 'So good it could not be better', while 78 per cent (404) of males and 70 per cent (362) of females labelled it as 'Very good' or 'Good' and the remainder rated it from 'Alright' to 'So bad it could not be worse'. Associations with QoL ratings have been reported elsewhere (Bowling 2005 $b$ ).

The main responses people gave, at both survey and in-depth interview, to the questions about what gave life quality were categorised into themes. In order of magnitude, these were: social relationships, social roles and activities, leisure activities enjoyed alone, health, psychological outlook and wellbeing, home and neighbourhood, financial circumstances, and independence. Smaller numbers mentioned many other things such as society/politics/government policy (e.g. on immigration and pensions), ageism, use of technology, and animal welfare. The majority of in-depth interview respondents also mentioned each of the main themes. Table I summarises the main QoL themes by the reasons given by survey respondents for their importance.

The main reasons given by people in their survey responses and in-depth interviews to explain the importance of these themes to their QoL were:

I. freedom to do the things they wanted to do without restriction (whether in the home or socially);

2. pleasure, enjoyment and satisfaction with life; mental harmony;

3. social attachment - having access to companionship, intimacy, love, social contact and involvement, help; social roles;

4. feeling secure.

These reasons, or enabling factors, cut across the main themes. In addition, there were inevitable inter-relationships between the main QoL themes, as the odds ratios presented in Table 2 show. A characteristic response from one respondent was, 'Health, friends and enough money ... those three things must be there to enjoy life. If you don't have that there is no purpose. With those, you are empowered to do as you so wish'.

Examples of the reasons people gave for the QoL theme's importance are illustrated next. Quotations and excerpts from interview transcripts that illustrate the main themes have been presented elsewhere (Bowling et al. 2003; Gabriel and Bowling 2004), so only those which specifically illustrate the sub-themes are presented here.

\section{Social relationships}

Social relationships were important to people for the closeness or intimacy, companionship and social contact they provided, including opportunities for conversation, support and instrumental aid. Also valued 
TA B L E I. Attributes that respondents said gave their lives quality (themes) and reasons given

\begin{tabular}{|c|c|c|c|c|c|c|}
\hline $\begin{array}{l}\text { Social relationships } \\
(8 \mathrm{I} \%)\end{array}$ & $\begin{array}{c}\text { Social roles and } \\
\text { activities }(60 \%) \text { and } \\
\text { other activities } \\
\text { enjoyed alone }(48 \%)\end{array}$ & $\begin{array}{l}\text { Having health } \\
\qquad(44 \%)\end{array}$ & $\begin{array}{l}\text { Psychological outlook/ } \\
\text { resources }(38 \%)\end{array}$ & $\begin{array}{c}\text { Home and } \\
\text { neighbourhood } \\
(37 \%)\end{array}$ & Finances $(33 \%)$ & $\begin{array}{l}\text { Independence } \\
\qquad(27 \%)\end{array}$ \\
\hline $\begin{array}{l}\text { Has partner/family/ } \\
\text { friends for: } \\
\text { Closeness/social contact } \\
\text { /compatibility/ } \\
\text { companionship/ } \\
\text { conversation } \\
\text { Doing things together/ } \\
\text { do things with } \\
\text { Empowerment } \\
\text { Intimacy/love } \\
\text { Pleasure }{ }^{1} \text { of company } \\
\text { Practical \& reciprocal } \\
\text { help } \\
\text { Security (to 'be there' if } \\
\text { needed)/sharing } \\
\text { responsibilities } \\
\text { Self-esteem/feeling } \\
\text { valued/'be nice to me' }\end{array}$ & $\begin{array}{l}\text { Attends local events/ } \\
\text { place of worship for } \\
\text { contact/activities } \\
\text { Mental pursuits for } \\
\text { alertness } \\
\text { Physical activity/ } \\
\text { walking for } \\
\text { exercise/fitness } \\
\text { Eats/drinks out for } \\
\text { enjoyment } \\
\text { Gardening for pleasure }{ }^{1} \\
\text { Leisure activities }^{2} \text { for } \\
\text { pleasure } \\
\text { Clubs/local groups for } \\
\text { contact }^{1} \\
\text { Holidays/outings for } \\
\text { pleasure } \\
\text { Pet for enjoyment } \\
\text { Music }{ }^{3} \text { for pleasure }{ }^{1} \\
\text { Reads for relaxation/ } \\
\text { enjoyment } \\
\text { TV/videos/music/ } \\
\text { wildlife for pleasure }{ }^{1} \\
\text { Security } \\
\text { Helps others }{ }^{4} \text { for } \\
\text { enjoyment/feeling } \\
\text { valued }{ }^{5} / \text { keeping }^{\prime} \\
\text { 'busy'/preventing } \\
\text { loneliness }\end{array}$ & $\begin{array}{l}\text { Feel empowered in } \\
\text { life } \\
\text { Lack of restriction } \\
\text { on life } \\
\text { Freedom from } \\
\text { discomfort/pain/ } \\
\text { aches/difficulty } \\
\text { sleeping } \\
\text { Ability to: do things } \\
\text { wants to do, own } \\
\text { personal/domestic tasks } \\
\text { Remain in own home } \\
\text { Participate in social } \\
\text { activities } \\
\text { Go out for pleasure }{ }^{1} \\
\text { Take holidays/travel } \\
\text { for pleasure } \\
\text { Drive car } \\
\text { Eat and drink what } \\
\text { one wants }\end{array}$ & $\begin{array}{l}\text { Positive outlook as } \\
\text { leads to focus on: } \\
\text { well-being/ } \\
\text { satisfaction with/ } \\
\text { acceptance of life } \\
\text { Feeling lucky } \\
\text { compared to other } \\
\text { people } \\
\text { Freedom from stress/ } \\
\text { loneliness } \\
\text { Good memories } \\
\text { Looking forward } \\
\text { Spiritual strength }\end{array}$ & $\begin{array}{l}\text { Home/ } \\
\text { neighbourhood } \\
\text { gives: } \\
\text { Pleasure } \\
\text { Home close to } \\
\text { friends/family for } \\
\text { social contact } \\
\text { Local amenities/ } \\
\text { transport/council } \\
\text { services for getting } \\
\text { out/security/ } \\
\text { convenience } \\
\text { Lack of crime for } \\
\text { security } \\
\text { Neighbourliness for } \\
\text { pleasure/social } \\
\text { contact/security }\end{array}$ & $\begin{array}{l}\text { Adequate to afford: } \\
\text { Amusements/ } \\
\text { hobbies/pastimes/ } \\
\text { pets for pleasure } \\
\text { Holidays/trips \& car/ } \\
\text { petrol to enable } \\
\text { holidays/trips for } \\
\text { pleasure }^{1} \\
\text { Freedom to enjoy } \\
\text { oneself } \\
\text { Getting out/shopping } \\
\text { Empowerment } \\
\text { Basic essentials for } \\
\text { security } \\
\text { House repairs/ } \\
\text { upkeep/bills for } \\
\text { security } \\
\text { Luxuries for pleasure }{ }^{1} \\
\text { Freedom from worry } \\
\text { about money } \\
\text { Security for future }\end{array}$ & $\begin{array}{l}\text { Pleasure from being } \\
\text { able to get out/have } \\
\text { holidays/social } \\
\text { contacts/activities } \\
\text { Enjoyment of life as } \\
\text { no-one else to } \\
\text { consider } \\
\text { Enjoyment from } \\
\text { having no work } \\
\text { restrictions on time } \\
\text { Freedom of time/ } \\
\text { work restrictions on } \\
\text { life } \\
\text { Freedom of } \\
\text { independence: } \\
\text { Still living in one's } \\
\text { own home/looking } \\
\text { after oneself and/or } \\
\text { home } \\
\text { Satisfaction of } \\
\text { looking after oneself }\end{array}$ \\
\hline
\end{tabular}

Notes: I Pleasure/enjoyment. 2 Arts, cinema, gambling. 3 By playing instrument/singing. 4 Through voluntary or committee work. 5 Purpose in life, social role. There were I I missing cases.

\section{CAMbridge JOURNALS}


$\mathrm{T}$ A B L E 2. Logistic regression showing odds of associations between quality of life themes

\begin{tabular}{|c|c|c|c|c|c|c|c|c|c|c|c|c|c|c|c|c|}
\hline & \multicolumn{2}{|c|}{$\begin{array}{l}\text { Social } \\
\text { relationships }\end{array}$} & \multicolumn{2}{|c|}{ Social activity } & \multicolumn{2}{|c|}{ Hobbies-solo } & \multicolumn{2}{|c|}{ Health } & \multicolumn{2}{|c|}{ Psychological } & \multicolumn{2}{|c|}{$\begin{array}{c}\text { Home/ } \\
\text { neighbourhood }\end{array}$} & \multicolumn{2}{|c|}{ Finance } & \multicolumn{2}{|c|}{ Independence } \\
\hline & OR & $95 \%$ CI & OR & $95 \%$ CI & OR & $95 \%$ CI & OR & $95 \% \mathrm{CI}$ & OR & $95 \%$ CI & OR & $95 \% \mathrm{CI}$ & OR & $95 \%$ CI & OR & $95 \% \mathrm{CI}$ \\
\hline $\begin{array}{l}\text { Social } \\
\text { relationships }\end{array}$ & & & I. 963 & $\begin{array}{l}\text { I. } 3^{8} 4^{-} \\
2.786\end{array}$ & I. $856^{* * * *}$ & $\begin{array}{r}\text { I. } 290- \\
2.67 \mathrm{I}\end{array}$ & І.о18 & $\begin{array}{l}0.89 \mathrm{I}^{-} \\
\mathrm{I} .837\end{array}$ & 0.963 & $\begin{array}{r}0.679^{-} \\
\text {I. } 367\end{array}$ & I. $663^{* * * *}$ & $\begin{array}{l}\text { I.I } 39^{-} \\
2.427\end{array}$ & 0.993 & $\begin{array}{c}\text { o. } 680- \\
\text { I. } 449\end{array}$ & 0.793 & $\begin{array}{r}0.540^{-} \\
\text {I.I } 65\end{array}$ \\
\hline Social activity & I. $833^{* * * *}$ & $\begin{array}{l}\text { I. } 292^{-} \\
2.600\end{array}$ & & & $2.477^{* * * *}$ & $\begin{array}{r}\text { I. } 882- \\
3.259\end{array}$ & $0.715^{*}$ & $\begin{array}{c}0.54^{2-} \\
0.943\end{array}$ & I.0o6 & $\begin{array}{r}0.763- \\
\text { I. } 328\end{array}$ & I.06o & $\begin{array}{r}0.799^{-} \\
\text {I.405 }\end{array}$ & 0.915 & $\begin{array}{r}0.675^{-} \\
\text {I. } 240\end{array}$ & I.O2I & $\begin{array}{r}0.745^{-} \\
\mathrm{I} .4 \mathrm{OI}\end{array}$ \\
\hline Hobbies - solo & $2.085 * * *$ & $\begin{array}{c}\text { I. } 44^{6-} \\
3.00\end{array}$ & $2.475^{* * *}$ & $\begin{array}{l}\text { I. } 88 \mathrm{I}- \\
3.256\end{array}$ & & & 0.939 & $\begin{array}{c}0.713- \\
\mathrm{I} .237\end{array}$ & I.оIо & $\begin{array}{r}0.769^{-} \\
\text {I. } 328\end{array}$ & І.058 & $\begin{array}{r}0.802- \\
\text { I.396 }\end{array}$ & $0.655^{* *}$ & $\begin{array}{r}0.4^{-} 4^{-} \\
0.887\end{array}$ & I. 606 & $\begin{array}{r}\text { I.180- } \\
2.187\end{array}$ \\
\hline Health & I. 329 & $\begin{array}{r}0.913- \\
\text { I.934 }\end{array}$ & $0.715^{* *}$ & $\begin{array}{r}0.54^{\mathrm{I}-} \\
0.943\end{array}$ & $0.94^{2}$ & $\begin{array}{r}0.715^{-} \\
1.24^{2}\end{array}$ & & & г.o63 & $\begin{array}{r}\text { o.809- } \\
\text { I.395 }\end{array}$ & I. $353^{*}$ & $\begin{array}{l}\text { I.028- } \\
\text { I. } .783\end{array}$ & $2.529^{\text {**** }}$ & $\begin{array}{l}\text { I. } 890^{-} \\
3.3^{8} 4\end{array}$ & 0.888 & $\begin{array}{r}0.65^{2-} \\
\text { I. } 210\end{array}$ \\
\hline Psychological & I.O2I & $\begin{array}{r}0.726- \\
\text { I. } 437\end{array}$ & I.OO & $\begin{array}{l}0.760- \\
1.322\end{array}$ & I.013 & $\begin{array}{r}0.772- \\
\text { I. } 333^{1}\end{array}$ & 1.063 & $\begin{array}{r}\text { o.809- } \\
\text { I.395 }\end{array}$ & & & 0.849 & $\begin{array}{c}0.645^{-} \\
\text {I.I } 8\end{array}$ & I. $414^{*}$ & $\begin{array}{l}\text { I.053- } \\
\text { I.899 }\end{array}$ & 0.802 & $\begin{array}{r}0.589^{-} \\
\text {I.093 }\end{array}$ \\
\hline $\begin{array}{l}\text { Home/ } \\
\text { Neighbourhood }\end{array}$ & I. $692^{* *}$ & $\begin{array}{r}\mathrm{I} .20 \mathrm{I}- \\
2.385\end{array}$ & I.06I & $\begin{array}{r}0.800- \\
1.407\end{array}$ & I.057 & $\begin{array}{r}\text { o.8oI- } \\
\text { I.395 }\end{array}$ & I. $354^{*}$ & $\begin{array}{r}\text { I.029- } \\
\text { I. } 783\end{array}$ & o. 848 & $\begin{array}{l}\text { o. } 644^{-} \\
\text {I.II7 }\end{array}$ & & & I.290 & $\begin{array}{c}0.954^{-} \\
1.745\end{array}$ & I.I79 & $\begin{array}{r}0.865^{-} \\
\text {ז.606 }\end{array}$ \\
\hline Finance & I.315 & $\begin{array}{r}0.927^{-} \\
\text {I.866 }\end{array}$ & 0.913 & $\begin{array}{r}0.674^{-} \\
\text {I. } 236\end{array}$ & o. $659^{* *}$ & $\begin{array}{r}0.487- \\
0.892\end{array}$ & $2.5^{16^{* * * *}}$ & $\begin{array}{l}\text { I. } 88 \mathrm{I}^{-} \\
3.366\end{array}$ & I. $399^{*}$ & $\begin{array}{r}\text { I.042- } \\
\text { I. } 878\end{array}$ & 1.285 & $\begin{array}{c}0.95^{--} \\
\mathrm{I} .73^{6}\end{array}$ & & & I. 234 & $\begin{array}{r}0.885^{-} \\
\text {I. } 722\end{array}$ \\
\hline Independence & 0.863 & $\begin{array}{r}0.594^{-} \\
\mathrm{I} .255\end{array}$ & I.022 & $\begin{array}{r}0.745^{-} \\
\text {I. } 400\end{array}$ & I. $600 * *$ & $\begin{array}{r}1.176- \\
2.176\end{array}$ & $0.93^{\circ}$ & $\begin{array}{c}0.68 \mathrm{I}- \\
\mathrm{I} .269\end{array}$ & 0.807 & $\begin{array}{c}0.593^{-} \\
\text {I.099 }\end{array}$ & I.182 & $\begin{array}{r}0.868- \\
\text { I.610 }\end{array}$ & $\mathrm{I} .25 \mathrm{I}$ & $\begin{array}{c}0.900- \\
\text { I. } 74 \mathrm{I}\end{array}$ & & \\
\hline
\end{tabular}

Notes: The odds ratios (OR) (exponential b) in the table are adjusted for age, sex and socio-economic status. Sample size: 8 Io. The themes are those mentioned as giving life quality or taking quality away from life (referent (comparison) value of $\mathrm{I}$, versus not mentioned $=0.4$ ). CI $=$ confidence interval.

Significance levels: $p<0.05 ; * * p<0.01 ; * * p<0.001 ; * * * p<0.0001$.

\section{CAMBridge JULRNALS}


were their contribution to one's self-esteem, feeling valued and loved, pleasure and enjoyment of life, and feeling secure. For example, as well as the need to have others to enjoy life with and companionship, respondents emphasised the importance of feeling cared for or loved, and for security and 'someone I can call on'. One 73-year-old widow said that her family provided the security of knowing that she was 'not completely alone in the world and knowing there's someone who cares about you'.

This security could compensate for other losses. For example, Mrs B was an 83-year-old widow who had moved closer to her daughter, on the other side of the country. She appreciated being near her daughter, going out with her, and enjoying music together. She had gained security by knowing if ever there was a problem, that her daughter was only a short distance away, and from feeling that her daughter no longer had to worry so much about her. But she had lost her close neighbour and friend, and independence as her new home was not within walking distance of shops. She had become dependent on her daughter for going out, but said:

If I'm honest I'd say (my quality of life has) mostly gone up a bit better. The main thing I miss is that walk down to the shops and that's where I'd meet people. But now, because I haven't got that, I never go out so I never meet anyone here, but having got my daughter makes up for it really. I've only got to phone and she'd be up like a shot if I was in trouble. In the other bungalow we did have a help-line, but if I suddenly fell down or anything I'd just have to manage somehow.

\section{Social and leisure activities}

Social roles and activities, including those enjoyed alone, were also important for enabling social contact and conversation, for keeping fit/alert, for pleasure and enjoyment, having a role, feeling valued, keeping busy and preventing loneliness. Involvement in local activities and voluntary work also enhanced people's sense of self-worth. For example, Mr P. who was married and aged 67 years, was a bell-ringer in his local church, and recently had helped to refurbish the bell-tower. He felt that helping others with his skills in turn helped him to feel valued: 'I feel that because ... I've got skills that I can apply which improve other people's (quality of life) ... I feel of value $\ldots$ and ... basically, they stop one vegetating'.

Mrs A said that doing voluntary work gave her life quality because it enabled her to remain involved in society and thereby enhanced her selfworth:

I enjoy people very much and I think being able to mix and socialise ... the church life ... to me is very important. I was secretary ... I am still in charge of flowers. I think the quality of life is being involved and having a part to play.

\section{CAmbridge}


I think if you lose your role in life then you start getting depressed. I think it is very important to be needed for whatever reason, ... and ... have self-worth or something, and know that people think you are worthy (Mrs A, 67-year-old widow).

\section{Health}

The main reasons why health gave life quality related to being free to do what they wanted to, lack of restrictions in domestic and social activities, and deriving pleasure and enjoyment from life. Mr D, a 66-year-old widower, emphasised the importance of his good health, which enabled him to take part in physical and leisure activities: 'I think that number one is having good health ... Because without that you are restricted ... I mean the other things follow on, like being able to go to the gym which I have just done, swim, we play bridge a lot'.

In contrast, Mrs $\mathrm{S}$, a widow aged 86 years, who was in poor health attributed her good quality of life to the mobility she still retained indoors, and which enabled her to remain living in her own home. She said, 'A friend comes in to wash me and I get help from others, which means I can keep on living in my own home. I can get about in the house ... just as long as I can stay in my own home'.

\section{Psychological outlook}

Positive psychological outlook and resources were said to give life quality because they led to acceptance and mental harmony and strength, a feeling of being lucky, unstressed, a focus on good memories rather than bad. These resources also helped people to look forward to things, and to be satisfied with life. For example, one woman, who lived with her husband, said:

I'm sure it does [outlook affects quality of life]. If we were ... always worrying about what's going to happen today or tomorrow, or looking on the black side ... then we certainly wouldn't enjoy life ... we're both of us very placid by nature generally, we look forward to life, and we have a good quality of life (Mrs D, 7I-year-old, married woman).

\section{Home and neighbourhood}

The reasons deriving from home and neighbourhood included neighbourliness, social resources which gave pleasure and enjoyment to life, amenities, convenience and security. Neighbourliness was said to be particularly important for helping people feel secure, as in the case of this widow who lived alone:

I feel very, very lucky, because the neighbours are excellent now, and this particular neighbour, this side, got the keys to the house ... when I'm not here they 


\section{${ }_{3} 8$ Ann Bowling and Zahava Gabriel}

come in (to check), because this is a troublesome area. Anyway, they come in later on and put the bedroom light on and then they switch it out ... just generally look after things .... that lady there ... often comes in for a cup of tea and a chat (Mrs J, 83-year-old widow).

\section{Finances}

Adequate finances contributes to life quality not just through being able to afford basic essentials and household bills, but because they enable one to enjoy oneself (e.g. through pastimes, holidays as well as luxuries), for freedom, security and lack of worry about having enough money. One 68-year-old married man said: 'It's having sufficient money ... to do what you require, run your car, say, and pay your bills, and have the odd holiday ... sufficient money not to have to worry about money'.

\section{Independence}

Having independence was said to contribute to pleasure/enjoyment and satisfaction with life by being able to socialise and have holidays, to look after oneself, and to being free from the time restrictions of working. ${ }^{2}$ Some valued the time flexibility of retirement from paid work and freedom from responsibilities, as in the case of a 76-year-old widower who said, 'If I decide I'm going to spend all day in bed and have bacon and eggs at two am, and go on holiday, or have a new suit, I can do them. Freedom for material things ... freedom from pressure'.

Some respondents, especially in remoter areas, were dependent on their cars for their overall QoL, and were concerned about how they would cope if they could no longer drive or afford to run a car. One 69-year-old married man said, 'At the moment we can drive but ... the quality of life will go down [without the car]. Everything is dependent on transport and it [public transport] is non-existent at the moment'.

\section{Multivariable analysis}

The structured variables selected for inclusion in the multivariate modelling of the independent predictors of self-rated QoL (see earlier for scale types and references) overlapped with the coded responses about what gave life quality (themes). However, not all of the underlying reasons were represented. Social relationships (including support) were represented by indicators of network size (summation of number of adults in household, number of 'close' friends, and number of relatives 'that you feel close to' who live within a $5_{5}^{-20}$ minutes walk or $5^{-}$- 0 minutes drive of the respondent), frequency score of face-to-face social contacts with relatives 
and friends, number of the five areas of life in which could call on someone for help and comfort, and number of supportive social services received (home care services, community occupational therapy, physiotherapy).

Social roles and activities were measured by number and type of different social activities engaged in over the past month (including voluntary work). Health was measured with scales of physical functioning, self-reported health status and reported long-standing illness. Psychological outlook and resources were represented by scales of psychological mood (GHQ-I2), selfefficacy and optimism. Home and neighbourhood were measured with ratings of the facilities in the neighbourhood (defined as 'within about a 15 or 20 minute walk or drive from your home'; leisure/social facilities, facilities for people aged $65+$, rubbish collection, local health services, transport, closeness to shops, somewhere nice to walk), ratings of area problems (speed/volume of traffic, noise, crime, air quality, litter/rubbish, graffiti), feeling safe to walk alone in the area night or day, feeling the area was neighbourly (proportion of people known and trusted), and enjoyment of living in the area. The study did not include measures of independence beyond health and physical functioning and income as enabling variables (see Health). Finances were measured with reported gross annual income.

Table 3 shows the distribution of respondents on selected variables by their QoL ratings. Respondents who reported their QoL overall to be at the 'good' end of the scale were more likely than others to have the most social support, better health status and physical functioning (ADL), to live in better quality areas that they enjoyed, and to have higher incomes. Age was not significantly associated with self-rated QoL, and sex was inconsistent (not shown in Table). Those who rated their lives overall as, 'So good, it could not be better' and, 'So bad, it could not be worse' were more likely to be males.

Logistic regression was used to examine the independent associations between the structured survey variables and self-rated QoL as 'good' or 'not good', adjusted for age and sex. As the QoL ratings were skewed towards the positive end of the scale, dichotomising them was appropriate for the analyses. The variables which achieved statistical significance at univariate level were entered into the full model, along with the perceived safety of the area, income and age on grounds of their a priori significance. A reduced model was then analysed, entering only those variables which retained significance in the full model.

Table 4 shows that the variables which retained statistical significance in both the full and reduced models were: number of areas can call for help or support in, health status, ADL score, ratings of the area, enjoyment of living in the area and income. None of the psychological variables retained significance in the full model; nor did other social network attributes, 
T a в L E 3. Self-rated QoL by selected independent variables

\begin{tabular}{|c|c|c|c|c|c|}
\hline & \multicolumn{5}{|c|}{ Quality of life: } \\
\hline & $\begin{array}{c}\text { So good, } \\
\text { could not } \\
\text { be better } \\
\%(\text { no.) }\end{array}$ & $\begin{array}{l}\text { Very good } \\
\%(\text { no.) }\end{array}$ & $\begin{array}{l}\text { Good } \\
\%(\text { no. })\end{array}$ & $\begin{array}{l}\text { Alright } \\
\%(\text { no.) }\end{array}$ & $\begin{array}{c}\text { Bad/very } \\
\mathrm{bad} / \mathrm{so} \text { bad } \\
\text { could not be } \\
\text { worse \% (no.) }\end{array}$ \\
\hline $\begin{array}{l}\text { Helped/supported in } \\
<5 \text { areas listed }\end{array}$ & 22 (II) & 2I $(9 \mathrm{I})$ & 32 (IOI) & $4^{\mathrm{I}}(6 \mathrm{o})$ & $54(\mathrm{I} 5)^{* * *}$ \\
\hline $\begin{array}{l}\text { Helped/supported in all } \\
5 \text { areas listed }\end{array}$ & $78(40)$ & $79(353)$ & $68(2 \mathrm{I} 2)$ & $59(87)$ & $4^{6}(\mathrm{I} 3)$ \\
\hline Health status: fair, poor & I3 (7) & I4 (64) & $30(95)$ & $54(79)$ & $67(20)^{* * * *}$ \\
\hline $\begin{array}{l}\text { Health status: excellent, } \\
\text { very good, good }\end{array}$ & $87(46)$ & $86(384)$ & $70(220)$ & $4^{6}(68)$ & $33($ (о) \\
\hline $\begin{array}{l}\text { ADL score less than } \\
\operatorname{good}(\operatorname{IO}+)\end{array}$ & $26(\mathrm{I} 4)$ & I2 (53) & $20(63)$ & $44(65)$ & $5^{0}(\mathrm{I} 5)^{* * *}$ \\
\hline ADL score good $(<\mathrm{IO})$ & $74(40)$ & $88(39 \mathrm{I})$ & $80(246)$ & $5^{6}(82)$ & $5^{\circ}(\mathrm{I} 5)$ \\
\hline $\begin{array}{l}\text { Area ratings score less } \\
\text { than good }(25+)\end{array}$ & I3 (7) & $8(37)$ & I6 (5o) & I7 (26) & $23(7)^{* *}$ \\
\hline Area ratings score good $(<25)$ & $87(46)$ & $9^{2}(4 \mathrm{IO})$ & $84(264)$ & $83($ (123) & $77(23)$ \\
\hline $\begin{array}{l}\text { Area perceived not safe }(5+) \\
\text { Area perceived as safe }(<5)\end{array}$ & $\begin{array}{l}\text { I2 (6) } \\
88(43)\end{array}$ & $\begin{array}{l}\text { I3 }(55) \\
87(369)\end{array}$ & $\begin{array}{l}\text { I6 (49) } \\
84\left(25^{2}\right)\end{array}$ & $\begin{array}{l}20(26) \\
80(\mathrm{IO} 2)\end{array}$ & $\begin{array}{l}22(6)^{+} \\
78(2 \mathrm{I})\end{array}$ \\
\hline $\begin{array}{l}\text { Does not enjoy living in area } \\
\text { Enjoys living in area }\end{array}$ & $\begin{array}{c}7(4) \\
93(50)\end{array}$ & $\begin{array}{c}5(23) \\
95(425)\end{array}$ & $\begin{array}{c}9(27) \\
9 \mathrm{I}(287)\end{array}$ & $\begin{array}{l}\text { I4 (2I) } \\
86(\text { (I29) }\end{array}$ & $\begin{array}{l}\text { I9 }(6)^{* *} \\
8 \mathrm{I}(25)\end{array}$ \\
\hline $\begin{array}{l}\text { Gross income: }<£ 7280 \\
£ 7280 \text { or more }\end{array}$ & $\begin{array}{l}62(3 \mathrm{I}) \\
3^{8}(\mathrm{I} 9)\end{array}$ & $\begin{array}{l}54(227) \\
46(194)\end{array}$ & $\begin{array}{l}56(\text { (170) } \\
44(\mathrm{r} 34)\end{array}$ & $\begin{array}{l}65(96) \\
35(5 \mathrm{I})\end{array}$ & $\begin{array}{l}\text { 7I }(22)^{++} \\
29(9)\end{array}$ \\
\hline Number of respondents & $43^{-54}$ & $39^{\mathrm{I}-449}$ & $283-3 \mathrm{I} 7$ & $\mathrm{I} 28-\mathrm{I} 5 \mathrm{O}$ & $27-3 \mathrm{I}$ \\
\hline
\end{tabular}

Notes: Only those variables entered into the reduced logistic regression model are displayed. $\mathrm{ADL}=$ Activities of Daily Living.

Significance levels: $* p<0.05 ; * * p<0.01 ; * * * p<0.001 ;+p=0.64 ;++p=0.143$.

social contacts, social activity, support from services, ratings of area problems, feelings of neighbourliness and safety or reported longstanding illness retain significance. Age and sex were not significant in either model (not shown).

The reduced model displayed in the table shows that the odds of rating QoL as good, compared to not good, were increased almost twofold for respondents with potential help/support in all five areas of life asked about, compared to those with less help/support. Respondents who rated their health status as 'Excellent' to 'Good' had over three times the odds of those with less good health of rating their QoL as good, rather than not good. Respondents with a good (low) ADL score had over twice the odds of rating their QoL as good. Respondents who rated their neighbourhoods as good in terms of facilities and services had almost twice the odds of those with less good ratings of rating their QoL as good, and those who enjoyed living in their areas had over twice the odds of those who did not 
T A в L E 4. Age-sex fully adjusted logistic regression showing the odds of associations (odds ratios and $95 \%$ confidence intervals) between independent variables and self-rated QoL as 'good' (I) versus 'not good' (o). Final and reduced models

\begin{tabular}{|c|c|c|c|c|c|c|}
\hline \multirow[b]{2}{*}{ Independent variables } & \multicolumn{3}{|c|}{ Full model } & \multicolumn{3}{|c|}{ Reduced model } \\
\hline & OR & $95 \% \mathrm{CI}$ & $\mathrm{p}$ & OR & $95 \%$ CI & $\mathrm{p}$ \\
\hline \multicolumn{7}{|l|}{ Social relationships and activities: } \\
\hline $\begin{array}{l}\text { Network size } 3+\text { people }(\mathrm{I}) \\
\text { vs. lower }(\mathrm{o})\end{array}$ & I.393 & $0.83 \mathrm{I}-2.335$ & 0.208 & & & \\
\hline $\begin{array}{l}\text { Can call on help/support in all } \\
5 \text { areas (I) vs. less than } 5 \text { (o) }\end{array}$ & І.695 & I.095-2.624 & 0.018 & I.887 & I. $260-2.826$ & 0.002 \\
\hline $\begin{array}{l}\text { High social contacts score } \\
<8 \text { (I) vs. lower }(\mathrm{o})\end{array}$ & 0.747 & $0.483^{-I . I 57}$ & o.19I & & & \\
\hline $\begin{array}{l}\text { Receives help from community } \\
\text { services (I) vs. does not }\end{array}$ & I.I $5^{2}$ & $0.93^{6-\mathrm{I} .4 \mathrm{I} 8}$ & 0.I82 & & & \\
\hline $\begin{array}{l}3 \text { or more social activities in } \\
\text { last month } 3+\text { activities } \\
\text { (I) vs. lower }(\mathrm{o})\end{array}$ & I. $45^{\mathrm{I}}$ & $0.940-2.240$ & 0.092 & & & \\
\hline \multicolumn{7}{|l|}{ Health and functioning: } \\
\hline $\begin{array}{l}\text { Health status: excellent } \\
\text { to } \operatorname{good}(\mathrm{I}) \text { vs. fair to poor }(\mathrm{o})\end{array}$ & 3.017 & I.906-4.778 & O.OOI & $3 \cdot 44^{\circ}$ & $2.268-5.2 \mathrm{I} 9$ & O.OOI \\
\hline $\begin{array}{l}\text { No reported longstanding } \\
\text { illness } \\
\text { (I) vs. one or more (o) }\end{array}$ & I. 248 & $0.747-2.084$ & 0.397 & & & \\
\hline $\begin{array}{l}\text { Activities of daily living score } \\
<\operatorname{ro} \operatorname{good}(\mathrm{I}) \text { vs. less than } \\
\text { good Io }+(\mathrm{o})\end{array}$ & $2.53^{\mathrm{I}}$ & I. $480-4 \cdot 33^{0}$ & o.OOI & $2 \cdot 5^{2 \mathrm{I}}$ & I. $59^{8}-3.977$ & o.OOI \\
\hline \multicolumn{7}{|l|}{ Psychological: } \\
\hline $\begin{array}{l}\text { GHQ no psychological } \\
\text { morbidity (score of }<5 \text { ) } \\
(\text { I) vs. some }(\text { score I-4) (I) }\end{array}$ & I. 323 & $0.823^{-2.128}$ & $0.24^{8}$ & & & \\
\hline $\begin{array}{l}\text { High self-efficacy - Io score } \\
\text { (I) vs. lower self-efficacy i I }+(\text { o) }\end{array}$ & I. 409 & $0.824-2.409$ & $0.2 \mathrm{II}$ & & & \\
\hline $\begin{array}{l}\text { High optimism score }-5 \text { score } \\
\text { (I) vs. less optimism } 5+\text { (o) }\end{array}$ & I. 279 & o.839-1.950 & 0.253 & & & \\
\hline \multicolumn{7}{|l|}{ Neighbourhood: } \\
\hline $\begin{array}{l}\text { Good area ratings }(<25) \text { (I) vs. } \\
\text { less than good }(25+)(\mathrm{o})\end{array}$ & I.706 & $0.99^{6-2.920}$ & 0.052 & I. 702 & I.02O-2.84I & 0.042 \\
\hline $\begin{array}{l}\text { Few problems in area } \\
\text { score }(24+) \\
(\text { I) vs. worse score }(<25) \text { (o) }\end{array}$ & $0.5^{8} 4$ & $0.329^{-1.037}$ & 0.066 & & & \\
\hline $\begin{array}{l}\text { Area perceived as } \\
\text { neighbourly (I) vs. not (o) }\end{array}$ & 0.978 & $0.643^{-\mathrm{I} .488}$ & 0.917 & & & \\
\hline $\begin{array}{l}\text { Area perceived as safe } \\
(<5)(\mathrm{I}) \text { vs. not }(5+)(\mathrm{o})\end{array}$ & เ. 676 & I.005-2.795 & $0.04^{8}$ & I. $5^{87}$ & $0.97 \mathrm{I}-2.595$ & 0.066 \\
\hline $\begin{array}{l}\text { Enjoys living in area (I) } \\
\text { vs. does not }(\mathrm{o})\end{array}$ & 2.343 & I. $243-4.4 \mathrm{I} 6$ & 0.008 & 2.143 & I. I97-3.837 & о.оIо \\
\hline \multicolumn{7}{|l|}{$\begin{array}{l}\text { Socio-economic and demographic } \\
\text { characteristics: }\end{array}$} \\
\hline $\begin{array}{l}\text { Gross annual income: More } \\
\text { than } £ 7280 \text { (I) vs. less } \\
\text { than this }(\mathrm{o})\end{array}$ & $\mathrm{I} .57 \mathrm{I}$ & I.OOI -2.465 & 0.049 & I. 634 & I.o69-2.498 & 0.023 \\
\hline
\end{tabular}

Notes: $\mathrm{CI}=$ confidence intervals. Referent (comparison) value $=\mathrm{I}$ versus o. The odds ratios (exponential b) in the table are adjusted for age and sex.

\section{CAMBrIDgE JDURALS}


of rating their QoL as good, rather than not good. Perceptions of the area as safe just missed significance in the reduced model, although respondents who felt the area was safe to walk in alone day or night had about one-and-a-half times the odds of those who felt it was not safe of rating their QoL as good rather than not good. Respondents with incomes exceeding $£ 7,280$ had about one-and-a-half times the odds of those on lower incomes of rating their QoL as good rather than not good. Independence was not adequately represented in the structured survey measures, although the enabling factors of health and functional ability, and income were included. As reported above, health and functioning did retain significance in the model, although income did not.

\section{Discussion}

This paper breaks new ground in presenting people's perceptions of the things that gave their lives quality (categorised as themes) and also their underlying reasons. It is based on lay theory, and built on the open-ended approach of the developers of the Schedule for the Evaluation of Individual Quality of Life (SEIQoL) (O'Boyle 1997), which is informed by a phenomenological perspective of working with the value system of the individual being assessed, rather than the value system of others. Like the SEIQoL, this paper departs from phenomenology in its use of mixed research methods (Bowling 2002). In addition, multivariable modelling examined the independent contribution that the theoretically informed, structured measures made to overall QoL.

The main reasons underlying the things people said gave their lives quality focused predominantly on: the freedom to do the things they wanted to do without restriction (whether in the home or socially); pleasure, enjoyment and satisfaction with life; mental harmony; social attachment - having access to companionship, intimacy, love, social contact and involvement, help; social roles; feeling secure. These linked the main QoL themes of social relationships, social roles and activities, health, psychological outlook and resources, home and neighbourhood, finances, and independence.

The results of the multivariate modelling show that it was not network size per se that contributed to perceived QoL, but whether respondents could call on others for help and support when needed. Unfortunately, the social relationships and support measures did not tap respondents' stated reasons of love, enjoyment, intimacy, pleasure, sharing, or feeling valued in this context. The results are consistent with the finding that social relationships was the most common QoL area mentioned: 8I per cent of

\section{CAMBRIDGE}


respondents said these gave quality to their lives. There is considerable literature on social support as a resource for practical help, emotional support and information (see Bowling 1994, 2005b), although little information about the precise ways in which this contributes to wellbeing (i.e. by providing closeness, companionship, social contact, conversation, doing things with someone, enjoyment, love, help, security, sharing, feeling valued).

Social network theory holds that the structure of the linkages between people determines the quality and efficiency of the interactive process in which information, emotional, instrumental and financial aid are obtained (Bowling 1994; Procidano and Heller 1983). There is strong evidence of their beneficial impacts on health and survival (Grundy, Bowling and Farquhar 1996; Seeman et al. 200I), and the measurement of social networks and support is common in epidemiological studies (Berkman and Glass 2000). Hypothesised causal pathways are psychosocial (strengthening physiological responses to health stressors; stress buffering effects), and through the provision of information (e.g. about health) (Cohen I988; Cohen and Syme I985; Seeman and Crimmins 200r). Social relationships may also enhance social role fulfilment, and thus self-identity and psychological wellbeing (Cohen I988; Cohen and Syme 1985). Methodological problems, however, are rife. Individual differences in perceived support needs may represent different expectations. Prior health status and the role of reverse causality have not always been adequately controlled for, and network changes can occur in response to changes in health and functioning and the consequent additional need for help and support (Miller and McFall ig9i).

Unexpectedly, social activities and other independent leisure pursuits, as the next most commonly mentioned contributor to QoL, did not retain significance in the full model. But the structured measure was simply a list of the number and type of social activities undertaken in the past month. A focused measure of actually having other people to do social activities with, feeling valued, enjoyment and reciprocity would probably have been more powerful. While the social disengagement theory of ageing (Cumming and Henry I96I) has long been discredited as simplistic, activity theory (Atchley I989) has also been criticised as unrealistic, given the role losses which accompany retirement and disability (Bengston and Schaie 1999). The theoretical focus in social gerontology is increasingly on the use of compensatory coping strategies (Baltes and Baltes i990). Thus a measure of social activities which incorporates lay values (reasons) as well as strategies of compensation, and their success, when certain social activities can no longer be undertaken (e.g. through frailty), would probably be more meaningful and sensitive than simple check-lists. 
Having one's health was mentioned by 44 per cent of respondents as contributing to their QoL. Health and functioning were also significant in the multivariate model. These have clear enabling functions across other domains of life (e.g. social participation, doing the things one wants to). The respondents reasoning included, for example, having health for empowerment, freedom, social participation, and doing what they wanted to as well as domestic and personal tasks. As well as enabling people to carry on with life physically, health is an enabling resource for achievement, meaning and purpose in life (Fisher 1995; Sarvimäki and Stenbock-Hult 2000). Health as an enabling factor for independence was inadequately captured by the survey questions (beyond ADL).

Unexpectedly, none of the psychological variables were significant in the model, even though a wide range of indicators was included. The domain was emphasised by $3^{8}$ per cent of respondents as giving life quality. Despite the many and diverse measures, they did not tap respondents' stated reasons of acceptance of life, good memories, looking forward to things, life satisfaction and spiritual strength. More sensitive measurement is needed to capture the reasons in lay theories and to enhance the sensitivity of quantitative measurement.

Over one-third of the respondents stated that their home and neighbourhood gave their lives quality. The neighbourhood variables that were significant in the multivariable model, and which overlapped with the respondents' stated reasons, were clear enabling factors in life - ratings of the quality of facilities in the area (e.g. leisure, facilities for older people, services and transport), and enjoyment of living in the area. Perceptions of the area as safe just missed significance in the final, reduced model, although the respondents who felt the area was safe to walk in alone day or night had about one-and-a-half times the odds of those who felt it was not safe of rating their QoL as 'good', rather than 'not good'. Perceptions of neighbourliness, and problems in the area (e.g. crime, vandalism, litter, traffic), were not significant in the model, although they were included in the respondents' reasons. Arguably, a socially-healthy environment, with a good infrastructure, contributes to QoL by providing a neighbourhood that promotes social contact, access (transport), facilities for basic needs (shops), pleasure (leisure facilities), and security (feeling safe).

Independence was inadequately represented in the model, although 27 per cent of the respondents mentioned it as giving their lives quality. Physical functioning (above) was a proxy indicator, along with income. Income (as well as health) was significant in the model; and it was mentioned as giving life quality by 33 per cent of the respondents. However, more complete measures of independence, freedom, and restriction are needed, that reflect the lay reasons given for enjoyment, freedom, 
satisfaction and related concepts. Independence, control and autonomy are essential for individual freedom. Indeed, Doyal and Gough (I99i) argued that health and autonomy are basic human needs, that are absolutes, not relative to individual cultures.

In sum, indicators which were not significant in the model did not fully incorporate lay values in their measurement properties. It is likely that those indicators which were significant could also have been improved. The findings of this study make a significant contribution to the literature on the meaning of QoL in older age. It is hoped that this will contribute to the development of a more sophisticated understanding of QoL, and thus to the development of more sensitive measures which capture it. As Popay (2006) has indicated, we need lay theories in order to achieve true understandings of social processes, and enhance our understanding of causal processes. This greater understanding is the challenge for future research on QoL.

\section{Acknowledgements}

Thanks are due to the ONS Omnibus Survey staff and ONS Qualitative Research Unit for overseeing the Quality of Life Interview and processing the data. Those who carried out the original analysis and collection of the data hold no responsibility for the further analysis and interpretation of them. Material from the ONS Omnibus Survey, made available through ONS, has been used with the permission of the Controller of The Stationery Office. The dataset is held at the Data Archive at the University of Essex. The research was funded by the Economic and Social Research Council (award no. L480254003 (Quality of Life). The Quality of Life Questionnaire was also part-funded by grants, held collaboratively, with Professor Christina Victor and Professor John Bond (L480254042; Loneliness and Social Isolation, also part of the ESRC Growing Older Research Programme), and with Professor Shah Ebrahim (Medical Research Council Health Services Research Collaboration: Health and Disability); the authors are grateful for their support.

\section{NOTES}

I The thematic data were audio-recorded and transcribed. The themes were coded and analysed using the NUD*IST software (for details see http://qsrinternational.com).

2 If respondents referred to the effects of 'independence' on their health and functioning, this was coded under 'Health'.

\section{References}

Andrews, F. M. (ed.) 1986. Research on the Quality of Life. Institute for Social Research, University of Michigan, Ann Arbor, Michigan.

Andrews, F. M. and Withey, S. B. 1976. Social Indicators of Well-being: American's Perceptions of Life Quality. Plenum, New York.

\section{CAMBridge}




\section{Ann Bowling and Zahava Gabriel}

Atchley, R. C. I989. The continuity theory of normal aging. The Gerontologist, 29, I83-90.

Baltes, P. B. and Baltes, M. M. (eds) I990. Successful Aging: Perspectives from the Behavioral Sciences. Cambridge University Press, New York.

Bengston, V. L. and Schaie, K. W. (eds) 1999. Handbook of Theories of Ageing. Springer Publishing Company, New York.

Berkman, L. F. and Glass, T. 200o. Social integration, social networks, social support and health. In Berkman, L. F. and Kawachi, I. (eds), Social Epidemiology. Oxford University Press, Oxford, I37-73.

Bowling, A. 1994. Social networks and social support among older people and implications for emotional well-being and psychiatric morbidity. International Review of Psychiatry, 9, $447-59$.

Bowling, A. 2001. Measuring Disease: A Review of Disease Specific Quality of Life Measurement Scales. Second edition, Open University Press, Maidenhead, Berkshire.

Bowling, A. 2002. Research Methods in Health. Investigating Health and Health Services. Open University Press, Maidenhead, Berkshire.

Bowling, A. 2005a. Measuring Health: A Review of Quality of Life Measurement Scales. Third edition, Open University Press, Maidenhead, Berkshire.

Bowling, A. 2005b. Ageing Well. Quality of Life in Old Age. Open University Press, Maidenhead, Berkshire.

Bowling, A. and Gabriel, Z. 2004. An integrational model of quality of life in older age: a comparison of analytic and lay models of quality of life. Social Indicators Research, 69, I- 36 .

Bowling, A., Banister, D., Sutton, S., Evans, O. and Windsor, J. 2002. A multidimensional model of QoL in older age. Ageing and Mental Health, 6, 355-7I.

Bowling, A., Gabriel, Z., Dykes, J., Marriott-Dowding, L., Evans, L., Fleissig, A., Banister, D. and Sutton, S. 2003. Let's ask them: a national survey of definitions of quality of life and its enhancement among people aged 65 and over. International fournal of Aging and Human Development, 56, 269-306.

Carver, D. J., Chapman, C. A., Thomas, V. S., Stadnyk, K. J. and Rockwood, K. 1999. Validity and reliability of the Medical Outcomes Study Short Form-20 questionnaire as a measure of quality of life in elderly people living at home. Age and Ageing, 28, I69-74.

Cohen, S. I988. Psychosocial models of the role of social support in the etiology of physical disease. Health Psychology, 7, 269-97.

Cohen, S. and Syme, S. L. I985. Issues in the study and application of social support. In Cohen, S. and Syme, S. L. (eds), Social Support and Health. Academic, Orlando, Florida, I-22.

Cooper, K., Arber, S., Fee, L. and Ginn, J. 1999. The Influence of Social Support and Social Capital on Health: A Review and Analysis of British Data. Health Education Authority, London.

Cumming, E. and Henry, W. 196r. Growing Old: The Process of Disengagement. Basic, New York.

Donovan, D. and Saunders, C. 2005. Key issues in the analysis of qualitative data in health services research. In Bowling, A. and Ebrahim, S. (eds), Handbook of Health Research Methods: Investigation, Measurement and Analysis. Open University Press, Maidenhead, Berkshire, 515-32.

Doyal, L. and Gough, I. I99I. A Theory of Human Need. Macmillan, London.

Fayers, P. M. and Hand, D. J. 2002. Causal variables, indicator variables and measurement scales: an example from quality of life. Fournal of the Royal Statistical Association, $\mathbf{1} \mathbf{6}_{\mathbf{5}}$, $2, \mathrm{I}-2 \mathrm{I}$.

Fisher, B.J. I995. Successful aging, life satisfaction, and generativity in later life. International fournal of Aging and Human Development, 4I, 239-50.

\section{CAMBridge JDURNALS}


Gabriel, Z. and Bowling, A. 2004. Perspectives on quality of life in older age: older people talking. Ageing and Society, 24, 675-9I.

Goldberg, D. P. and Williams, P. I988. A User's Guide to the General Health Questionnaire. NFER-Nelson, Windsor, Berks.

Grundy, E. and Bowling, A. I999. Enhancing the quality of extended life years. Identification of the oldest old with a very good and very poor quality of life. Ageing and Mental Health, 3, I99-212.

Grundy, E. Bowling, A. and Farquhar, M. 1996. Social support, life satisfaction and survival at older ages. In Casselli, G. and Lopez, A. (eds), Health and mortality among elderly populations. pp. I35-56. Clarendon Press, Oxford.

Haywood, K. L., Garratt, A. M., Mackintosh, A. E. and Fitzpatrick, R. 2004. Health Status and Quality of Life in Older People. A Structured Review of Patient-assessed Health Instruments. Patient-assessed Health Instruments Group, University of Oxford, Oxford.

Higgs, P., Hyde, M., Wiggins, R. and Blane, D. 2003. Researching quality of life in early old age: the importance of the sociological dimension. Social Policy and Administration, 37, 239-52.

Hyde, M., Wiggins, R. D., Higgs, P. and Blane, D. 2003. A measure of quality of life in early old age: the theory, development and properties of a needs satisfaction model (CASP-r9). Ageing and Mental Health, 7, r86-94.

Lau, R. R., Hartman, K. A. and Ware, J. E. I986. Health as a value: methodological and theoretical considerations. Health Psychology, 5, 25-43.

Lawton, M. P. ig82. Competence, environmental press and adaptation of older people. In Lawton, M. P., Windley, P. G. and Byerts, T. O. (eds), Aging and environment. Theoretical approaches. Springer, New York.

Lawton, M. P. I983a. Environment and other determinants of well-being in older people. Gerontologist, 23, 349-57.

Lawton, M. P. I983b. The varieties of wellbeing. Experimental Aging Research, 9, $65-72$.

Lawton, M. P. I991. A multidimensional view of quality of life in frail elders, In Birren, J. E., Lubben, J., Rowe, J. and Deutchman, D. (eds), The concept and measurement of quality of life in the frail elderly. pp. 4-27. Academic Press, San Diego, CA.

Lawton, M. P. I996. Quality of life and affect in later life. In Magai, G. and McFadden, S. H. (eds), Handbook of emotion, human development, and aging. pp. 327-48. Academic Press, San Diego, CA.

Maslow, A. I954. Motivation and Personality. Harper, New York.

Maslow, A. H. I968. Toward a Psychology of Being. 2nd ed. Van Nostrand, Princeton, New Jersey.

Miller, B. and McFall, S. г99ı. Stability and change in the informal task social support network of frail older persons. The Gerontologist, 31, 735-45.

O'Boyle, C. A. I997. Quality of life assessment: a paradigm shift in healthcare? Irish fournal of Psychology, $\mathbf{1 8}, 51 \mathrm{10}-66$.

Office for National Statistics 2000. Standard Occupational Classification. 'Volume I: Structure and Descriptions of Unit Groups' and 'Volume 2: The Coding Index'. Office for National Statistics, London.

Popay, J. 2006. Whose theory is it anyway? Fournal of Epidemiology and Community Health, 6o, $57 \mathrm{I}-72$.

Procidano, M. E. and Heller, K. I983. Measures of perceived social support from friends and from family: three validation studies. American Fournal of Community Psychology, II , I-24.

Rogerson, R. J., Findlay, A. M., Coombe, M. G. and Morris, A. I989. Indicators of quality of life. Environment and Planning, 2 I, I655-66.

\section{CAMBridge}




\section{Ann Bowling and Zahava Gabriel}

Sarvimäki, A. and Stenbock-Hult, H. B. 200o. Quality of life in old age described as a sense of well-being, meaning and value. Fournal of Advanced Nursing, 32, I025-33.

Schwarzer, R. 1993. Measurement of Perceived Self-efficacy: Psychometric Scales for Cross-cultural Research. Institute for Psychology, Free University of Berlin, Berlin.

Scheier, M. F. and Carver, C. S. I985. Optimism, coping, and health: assessment and implications of generalised outcome expectancies. Health Psychology, 4, 219-47.

Seeman, T. A. and Crimmins, E. 200I. Social environment effects on health and ageing: integrating epidemiological and demographic approaches and perspectives. In Weinstein, M., Hermalin, A. I. and Stoto, M. A. (eds), Population Health and Aging: Strengthening the Dialogue Between Epidemiology and Demography. New York Academy of Sciences, New York, 88-iI7.

Seeman, T. E., Lusignolo, T. M., Albert, M. and Berkman, L. 200ı. Social relationships, social support, and patterns of cognitive aging in healthy, high functioning older adults: MacArthur studies of successful ageing. Health Psychology, 2o, 243-55.

Sherbourne, C. D. and Stewart, A. L. I99I. The MOS social support survey. Social Science and Medicine, 32, 705-14.

Skevington, S. M. I999. Measuring quality of life in Britain: introducing the WHOQOLI0o. Psychomatic Research, 47, 449-59.

Skevington, S. M., O'Connell, K. A. and the WHOQOL Group. 2004. Can we identify the poorest quality of life? Assessing the importance of quality of life using the WHOQOL-Ioo. Quality of Life Research, 1 3, 23-34.

Skevington, S. M., Lotfy, M. and O'Connell, K. A. 2004. The World Health Organization's WHOQOL-BREF quality of life assessment: psychometric properties and results from international field trials. A report from the WHOQOL Group. Quality of Life Research, 1 3, 299-310.

Stenner, P. H. D., Cooper, D. and Skevington, S. M. 2003. Putting the Q into quality of life; the identification of subjective constructions of health-related quality of life using Q methodology. Social Science and Medicine, 57, 216I-72.

Townsend, P. I979. Poverty in the United Kingdom. Pelican, Harmondsworth, Middlesex.

Ware, J. E., Snow, K. K., Kosinski, M. and Gandek, B. I993. SF-36 Health Survey: Manual and Interpretation Guide. The Health Institute, New England Medical Center, Boston, Massachusetts.

Ware, J. E., Snow, K. K., Kosinski, M. and Gandek, B. 1997. SF-36 Health Survey: Manual and Interpretation Guide. Revised edition, The Health Institute, New England Medical Center, Boston, Massachusetts.

World Health Organisation. 1993. Measuring Quality of Life: the Development of the World Health Organization Quality of Life Instrument (WHOQOL). WHO, Geneva.

Accepted 6 June 2007

Address for correspondence:

Department of Primary Care and Population Sciences, University College London, Hampstead Campus, London $\mathrm{NW}_{3}{ }_{2} \mathrm{PF}$.

email: a.bowling@ucl.ac.uk

\section{CAMBridge JDURNALS}

